\title{
Romantic Beliefs and Myths in Spain
}

\author{
Ana Barrón López de Roda, David Martínez-Íñigo, Pilar de Paúl, and Carlos Yela* \\ Complutense University of Madrid
}

\begin{abstract}
Data from a representative sample of the Spanish population ( 1,949 participants between ages 18 and 65) were analyzed to examine the strength of the principal romantic myths and the link between sex, love, and marriage in Spair. A survey was made up and was administered by interviewers. The results show the strength of these myths and the relationship between the three above-mentioned variables. Women, people with fewer years of formal education, and older people were more likely to believe in the myths and the relation between sex, love, and marriage was stronger in these groups. The findings ate discussed in terms of different psychosocial theories.

Key words: romantic myths, sex, love, marriage
\end{abstract}

En este artículo se analizan los datos de una investigación realizada con una muestra representativa de la población española respecto a la vigencia de los principales mitos románticos y la vinculación entre sexo, amor y matrimonio. Se elaboró un cuestionario para evaluar dichas variables, que fue administrado, en forma de entrevista, a 1.949 personas. Los resultados indican la gran vigencia de dichos mitos y la estrecha relación entre las tres variables indicadas anteriormente, especialmente en el caso de las mujeres, personas de mayor edad y con menor nivel de estudios. Los resultados se comentan desde diferentes teorías psicosociales.

Palabras claves: mitos románticos, sexo, amor, matrimonio

* Authors appear in alphabetical order.

This paper is part of the research "Loving Behavior: A representative sample of Spanish population," funded by the Comisión Interministerial de Ciencia y Tecnología, carried out by J. L. Sangrador García, A. Barrón López de Roda, P. de Paúl Velasco, C. Yela García, and D. Martínez Iñigo, and supervised by Florencio Jiménez Burillo.

Correspondence concerning this article should be addressed to Dr. Ana Barrón López de Roda, Departamento de Psicología Social. Facultad de Psicología. Universidad Complutense de Madrid. Campus de Somosaguas. 28223 Madrid (Spain). 
Since Rougemont's (1938) and Burgess and Locke's (1945) pioneer works, myths and cultural beliefs concerning love, marriage, sex and the interconnection between them has been considered a key issue to understand intimate relationships (Cancian, 1987; Crosby, 1973; Goode, 1959; Hetch, Marston, \& Larkey, 1994; Kayser, 1993; MartínezÍfiigo, 1997; Noller, 1996; Solomon, 1988; Yela, 1995, 1996. 1997, 1998). Recently, Dion and Dion (1996) have claimed more attention for cultural variables related to close relationships. Despite the universal or particular nature of love, the main issue has been the meaning and function that each culture, throughout different historical periods, has assigned to love, and the consequences this has on intimato relationships (Jankowiak \& Fisher, 1992). Taking into account the main role love plays in human happiness, health, and general satisfaction (Argyle, 1987; Barrón, 1990), and the relevance to the social structure of interpersonal relations based on love, matriage is still the comerstone of the family in our culture (Simpson, Campbell, \& Berscheid, 1986; C.I.R.E.S, 1992). One can see that scientific knowledge of these issues could offer solutions about how to confront and solve the problems, which may emerge in and from relationships.

Some authots, belonging to academic research and clinical practice, have pointed out that expectations, beliefs, and the meaning that subjects attach to some events in their intimate relationships are sources of disappointment, lack of affection, and instability (Beck, 1988; Dion \& Dion, 1996; Ellis \& Grieger, 1977; Kayser, 1993; Noller, 1996). Most of these beliefs are cultural constructs shared by individuals. Each historical period has developed a different view of love, sex, and marriage; consequently, the relationship between these three elements has changed throughout time. In ancient Greece, affective relationships (hetero- and fundamentally homosexual) were closely linked to the sexual sphere and clearly separated from marriage. In marriage, only the wife was required to be sexually faithful to her husband, and the purpose of sex was exclusively procreation. During the Roman Empire, erotic and recreational pleasure was also separate from marriage, linked to occasional and sporadic conquests. In the High Middle Ages, love, marriage, and sexual pleasure were regarded as three independent entities to be satisfied in different relationships. From the 16 th to the 18 th century, arranged marriage continued to exist simultaneously with extramarital "romantic love," which was nonsexual, originating in medieval genteel love. Since the beginning of the 19th century, the links between the romantic love concepts, marriage, and sexuality emerge, and this trend was consolidated in our century. From then on, romantic love ceased to be minority and became popular and normative. Marriage emerged as a personal choice; both romantic love and sexual satisfaction should be satisfied within marriage or a stable relationship (Fisher, 1992; Hendrick \& Hendrick, 1992; Iglesias de Ussel, 1987; Malo de Molina, 1992; Martín Gaite, 1987; Ortega y Gasset, 1926, 1952; Rougemont, 1938; Solomon, 1988; Yela, 1995).

Taking into account this historical process and the initial considerations about culture and intimate relationships, we carried out a survey on a representative sample of the Spanish population in order to explore whether lay people hold the beliefs that some authors define as distinctive of contemporary love (Averill \& Boothroyd, 1977; Cook \& McHenry, 1978; Good, 1976; Hendrick \& Hendrick, 1992; Liebowitz, 1983; Peele, 1975; Schaef, 1989; Simon, Eder, \& Evans, 1992; Simpson et al., 1986; Sternberg, 1988; Tennov, 1979; Van Sommers, 1987). We classified these beliefs, using the recent review of scientific literature on intimate-relationship beliefs carried out by Yela (1995). We consider this classification useful for our research aims. Concretely, we assessed the following myths or beliefs:

1. The equivalence myth: love understood necessarily as a strong passion, supposedly the same as "being in love" (so that if one does not feel the same passion as in the first days, it means one does not really love one's partner, and should therefore put an end to the relationship).

2. The "better-half" myth: the belief that, in some way, there is someone predestined for each person.

3. The exclusiveness (of being in love) myth: which assumes that it is impossible to be in love with two people at the same time.

4. The eternal passion myth: the belief that the intense passion of the first stages, if it is real, will last, or it should last, forever.

5. The omnipotence (love conquers all) myth: which implies that trusting real love will get around and overcome all obstacles.

6. The fidelity myth: which, in its extreme formulation, supposes that if someone is really in love, he or she will always be sexually faithful to the partner (therefore, if one is not faithful, one does not really love one's partner).

7. The marriage myth: which considers that love, that is, passion or being in love, is the one and only reason for marriage.

8. The couple myth: which states that the couplerelationship is inherent to human nature and, as such, present in all eras and cultures.

As tentative hypothesis, we posited that most people in Spain, as in other western countries, would hold these beliefs, which we called romantic myths. Moreover, we explored the differences according to sex, age, and social and cultural level. Finally, we were interested in the connection between these myths, marriage, and sex. According to the historical process described above, we expected to find a strong connection between these three elcments. The role of sociodemographic variables was also considered. This is the first time these issues were empirically tested on a representative sample of Spanish population. 


\section{Method}

\section{Participants}

Participants were Spanish men $(n=955)$ and women $(n$ $=994$ ), ranging from 18 to 65 years of age, living in towns of over 2,000 inhabitants, including island provinces. In all, 1,949 interviews were carried out. The participants were divided into live age ranges: $18-24$ years old $(n=367)$, 25$34(n=487), 35-44(n=398), 45-54(n=329)$, and 55-64 $(n=366)$.

We employed multiple steps and layers by clusters. selecting sample primary units (towns) and secondary units (sections) randomly, and the smallest units (individuals) by random paths and quotas of sex and age. The layers were formed by correlating the 17 regions to the size of habitat, divided into seven categories: less than 2,000 inhabitants; 2,001 to 10,000 inhabitants; 10,001 to 50,000 ; 50,001 to 100,$000 ; 100,001$ to 400,$000 ; 400,001$ to 1,000,000; and over a million inhabitants. The sample error, at the level of confidence of $95.5 \%$, was \pm 2.23 for the whole sample.

\section{Measures}

From the above-mentioned theoretical backgrounds, a survey was created, which gathered information about the following variables: degree of support of romantic myths, link between love, sex, and marriage, sociodemographic variables (such as sex, age, and education,) and the other factors that the previous review of specialized literature on love show to be related theoretically or empirically to love relationships, sexual attitudes, sexual behavior, jealousy, and duration of the relationship (Yela, 1995). The survey was administered in the form of interviews, between July 5 and 30, 1995.

Romantic myths. Each myth was assessed with a specific item, which was simply the description of the myth (see above), with which the subject expressed his or her degree of agreement on a 5-interval continuum: $1=$ strongly disagree $2=$ disagree $; 3=$ neutral or medium; $4=$ agree $;$ and $5=$ strongly agree. The alternatives "don't know" and "no reply" were added. We also obtained a global myth score for each subject, which was the mean of the subject's scores on the myth items.

Link between sex, love, and marriage. A set of items, including the separation between each possible combination of two elements from the trio "sex, love, and marriage," assessed the connection between these three elements. The subject specified his or her level of agreement on a 5 interval continuum, where 1 = elements were completely connected and $5=$ elements were completely separate. Therefore, subjects had to decide whether to explicitly accept or rcject (point 3 being medium or neutral) sex without marriage, love without marriage, sex without love, love without sex, martiage without sex, and marriage without love. A general score for sex-marriage-love separation was also calculated, represented by the mean of the six preceding scores.

Feelings of jealousy. Two dimensions of jealousy (emotional and sexual, according to Butnk \& Bringle, 1987) were assessed by two items, with which the subject expressed his or her degree of agreement on a 5 -interval continuum, where $1=$ strongly disagree , and $5=$ strongly agree. Emotional jealousy refers to the partner's intimacy with other people, and sexual jealousy refers explicitly to sexual relationships.

Atitude owards fidelity. Subjects were requested to express the importance of fidelity for them on a 4-interval continuum, where $1=$ not at all important, and $4=$ very important.

Attraction towards others. Measured by two items, subjects were requested to choose from seven categories, indicating the number of people to whom they had felt sexually (on one item) and emotionally (on the other) atracted. These categories were: "none," "l," "2 to 4 ," "5 to $10, "$ "1l to $20, "$, "21 to 100 ," "more than 100 ."

Sexual experience. As with feelings of sexual attraction towards others, subjects were requested to check one category. indicating with how many people they had had sexual relations, using the same categories as mentioned above.

Years of formal education. One question requested subjects to indicate the level of formal cducation they had achieved.

Religions beliefs and behavior. Seven options were offered: Catholic, other religions, indifferent, agnostic, atheist, an open option, and "I don't know or no reply". We grouped together the "beljevers" (Catholics and other religions) on the one hand, and the "non-believers" (atheists and agnostics) on the other. We also asked about the frequency of attending church services (categories were never, a few times a year, a few times a month, almost every Sinday, and several days a week).

Finally, we also asked subjects about their sex, age, and duration of their relationship.

\section{Results and Discussion}

\section{Romantic Myths}

The first data analysis provided us with the global percentages, the difference of mean scores between men and women, and Pearson's correlations between certain sociodemographic variables, such as age and level of studies. It is important to note the strength of romantic myths in romantic relationships in our society nowadays (sce Tables 1 and 2). 
Table 1

Percentage of Believers in Myths; Means, Standard Deviations, and Differences in Romantic Myfhs, according to Sex

\begin{tabular}{|c|c|c|c|c|c|c|c|c|c|c|}
\hline \multirow[b]{2}{*}{ Myth } & \multirow[b]{2}{*}{$\%$ believers } & \multicolumn{3}{|c|}{ Men } & \multicolumn{3}{|c|}{ Women } & \multirow{2}{*}{$\frac{\text { Difference }}{t}$} & \multicolumn{2}{|c|}{ Total } \\
\hline & & $M$ & $S D$ & $n$ & $M$ & $S D$ & $n$ & & $M$ & $S D$ \\
\hline Equivalence & 45 & 3.12 & 1.18 & 924 & 3.10 & 1.26 & 965 & - & 3.11 & 1.22 \\
\hline "Better-half" & 50 & 3.04 & 1.26 & 934 & 3.34 & 1.21 & 964 & $-5.32^{*}$ & 3.19 & 1.24 \\
\hline Exclusiveness & 55 & 3.23 & 1.26 & 934 & 3.39 & 1.30 & 966 & $-2.69^{*}$ & 3.31 & 1.28 \\
\hline Eternal Passion & 65 & 3.56 & 1.16 & 938 & 3.59 & 1.23 & 971 & - & 3.57 & 1.02 \\
\hline Omnipotence & 75 & 3.84 & 1.05 & 943 & 3.99 & 1.02 & 966 & $-3.35^{*}$ & 3.91 & 1.03 \\
\hline Sexual Fidelity & 80 & 3.91 & 0.99 & 947 & 4.16 & 0.91 & 987 & $-5.86^{*}$ & 4.03 & 0.96 \\
\hline Marriage & 85 & 3.99 & 1.03 & 944 & 4.23 & 0.86 & 990 & $-5.69^{+}$ & 4.11 & 0.95 \\
\hline Couple & 95 & 4.30 & 0.68 & 947 & 4.37 & 0.65 & 990 & - & 4.33 & 0.66 \\
\hline Global myth score & $75 \%$ & 3.63 & 0.58 & 865 & 3.78 & 0.57 & 875 & $-5.54^{*}$ & 3.71 & 0.57 \\
\hline
\end{tabular}

Note. Empty cells indicate statiscally nonsignificant differences.

$* p<.01$

Table 1 reveals that $75 \%$ of the sample scored higher than 3 on the global myth score (which measured agreement with romantic myths). Only $15 \%$ scored 3 or below (the remaining $10 \%$ did not reply to any myth items).

Concerning significant sex differences, Table 1 shows that women expressed stronger belief in live of the eight myths (better-half, exclusiveness, omnipotence, sexual fidelity, and marriage). The fact that women believed in romantic myths more than men is in accordance with the greater value they place on romanticism in occasional relationships as well as in stable ones (Dion \& Dion, 1979; Houston, 1981). On the one hand, sex differences can be explained by the differential socialization process of sex. Sociobiologists point out that to choose a love-sex strategy, which would nowadays be considered romantic, has higher reproductive value for women, probably because of their greater adaptive capacity from an evolutionary point of view.
When we consider the myths altogether, we also observed a slightly stronger belief in women (general means were 3.63 and 3.78 for men and women, respectively, $p=.000$, as scen in Table 1).

Although the sex differences were statistically significant, they were still small and the mean for men (lower than that of women) for all myths was always over 3 (the so-called medium range value - although we cannot be sure of the psychological meaning of that central value as a "medium" or "central" point, as acknowledged by all researchers on attitudes). There were no statistically significant differences in the equivalence myth $(M=3.12$ and 3.10 for men and women, respectively), the eternal passion myth $(M=3.56$ and 3.59 for men and women, respectively), and the couple myth ( $M=4.30$ and 4.37 for men and women, respectively). This shows the strength of romantic myths in today's Spanish population.

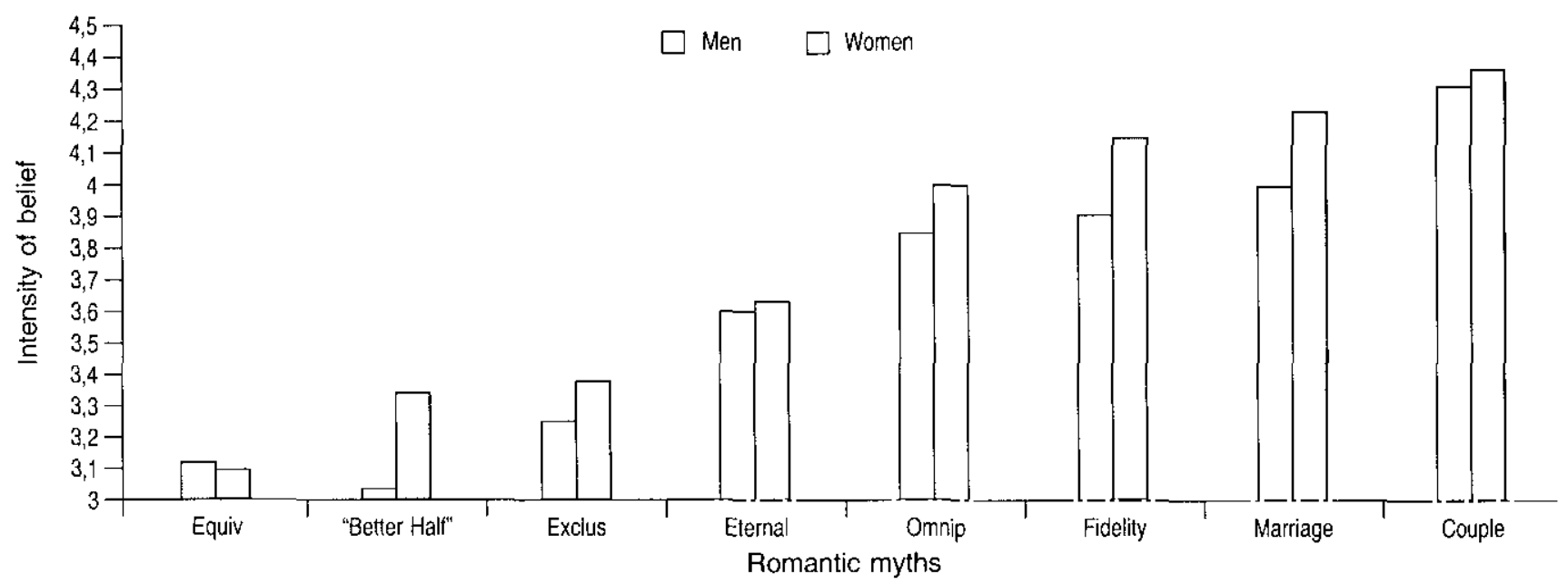

Figure /. Intensity of the belief in romantic myths in the Spanjsh population. 
As displayed in Table 2, the majority of the romantic myths correlate positively, although only moderately, with age (the correlation between age and the global score was $r=.22, p=.000$ ). The differences between the romantic beliefs of the youngest group (18-25 years) and the oldest group (55-65 years) - where the greatest differences were observed - were almost always relatively small, and, in any case, smaller than expected (assuming that young people possess certain characteristics, such as rebelliousness, nonconformity, etc.). It may be that the new generations are somehow more conservative than the previous ones, and this includes issues of love and sex. However, romantic myths seem to be very extended.

Concerning the correlations between romantic myths and level of studies (see Table 2), they were, in general, negative and statistically significant at the Ievel of confidence of $99 \%$. In some cases, such as the eternal passion myth and the global myth score, the correlation was higher than $r=$ $.25, p=.000$.

Significant correlations and differences also appeared when taking into account religious beliefs. Agnostics and atheists $(n=177)$ scored 3.25 on the global myth score, whereas believers (almost all were Catholics) scored 3.80, $p$ $=.000$. Religious behavior was positively and significantly related to all myths, and also to the global myth score, $r=$ $.25, p=.000$. Therefore, belief in romantic myths was stronger for Catholics and people with a lower level of education, and weaker for agnostics and people with higher education levels.

However, as shown in Tables 1 and 2, we will analyze each myth separately:

1. The equivalence myth. This was accepted by $45 \%$ of the sample (scoring 4 or 5 ), whereas $40 \%$ rejected it (scoring 1 or 2 ; only $7 \%$ totally disagreed), and the remaining $15 \%$ were made up of those who were doubtful (scoring 3) or did not reply. There were no statistically significant differences in sex or age, but, on the other hand, we found a statistically significant negative relation with the level of studies, $r=-$ $.14, p<.01$. Belief in this myth has a notable effect on romantic relationships. Psychosocial investigations have stated that physiological, psychological, and interpersonal relation processes, typical of the intense state of "falling and being in love," slowly fade away and turn into different processes as the relationship develops (Liebowitz, 1983; Solomon, 1980; Sternberg, 1988; Wilson, 1981; Yela, 1997). That is why it is important for both members of the couple to accept this change as something natural instead of experiencing it as traumatic, as is usually the casc.

2. The better-half myth. This myth was accepted by $50 \%$ of the sample, whereas $35 \%$ disagreed (answers in total disagreement did not reach $10 \%$ ). This is where sex differences were more pronounced (but only 3.34 vs. 3.04 for women and men, respectively). Women agreed more, as with the rest of the myths. Results showed that belief in this myth increased with age, $r=.13, p<.01$, and tended to decrease with the level of studies, $r=-.20, p<.01$.
Table 2

Correlations between Romantic Mythis, Age, and Studies

\begin{tabular}{lcccc}
\hline & \multicolumn{3}{c}{ Age } & \multicolumn{2}{c}{ Sudies } \\
\cline { 2 - 5 } Myth & $r$ & $n$ & $r$ & $n$ \\
\hline Equivalence & & 1887 & $-.14^{*}$ & 1883 \\
"Better-halt" & $13^{*}$ & 1896 & $-.20^{*}$ & 1892 \\
Exclusiveness & $.15^{*}$ & 1898 & $-.10^{*}$ & 1894 \\
Eternal Passion & $.17^{*}$ & 1907 & $-.26^{*}$ & 1903 \\
Omnipotence & $.18^{*}$ & 1907 & $-.21^{*}$ & 1903 \\
Sexual Fidelity & $.18^{*}$ & 1932 & $-.18^{*}$ & 1928 \\
Marriage & $.15^{*}$ & 1932 & $-.13^{*}$ & 1928 \\
Couple & - & 1935 & -- & 1931 \\
\hline Globla myth score & $-.22^{*}$ & 1738 & $-.30^{*}$ & 1734 \\
\hline
\end{tabular}

Note. Empty cells indicate statiscally nonsignificant differences. $* p<.01$

3. The exclusiveness of being in love myth. This was accepted by $55 \%$ of the simple (only $8 \%$ disagreed totally). More women tended to share the belief, as did older people and those with a lower level of studies, although these differences were not large in either case.

4. The etemal passion myth. This myth is a problem becanse, sooncr or later, it contradicts reality - due to wellknown physiological, psychological, and interpersonal processes, for example, saturation, reduction of uncertainty, tolerance, the Coolidge effect, the law of changing emotions, etc. (Frijda, 1988; Skinner, 1953; Solomon, 1980; Wilson, 1981). Nevertheless, it was shared by approximately two thirds of the sample, whereas barely $5 \%$ of the sample disagreed totally with the myth. Both men and women believed in it: this myth correlated positively with age, $r=$ $.17, p<.01$, and was the one with the highest correlation with the level of studies, $r=-.26, p<.01$.

5. The omipotence myth. This myth was accepted by $75 \%$ of the sample; only $2 \%$ disagreed totally. As with the previous myths, the belief was weaker among the youngest and those with a higher level of studies. Up $1085 \%$ of the people with no studies and about half of the postgraduates accepted this belief as true.

6. The fidelity myth. This was accepted by $80 \%$ of the sample, whereas only $1 \%$ disagreed totally (note that the myth does not refer to the importance of fidelity but to its consideration as a necessary condition for true love). This could be taken as proof of the immense power of socialization in controlling biological instincts. On the other hand, although women agreed with the myth significantly more than men, the difference was quite small, and the pereentage of men was higher one would expect (over 75 $\%$ of the men agreed with it) if the forces on which sociobiology focuses were the only ones (or the predominant ones) that influence affective-sexual behavior. Furthermore, 
Table 3

Percentage of Acceptance of Dissociation of Lone-Sex-Marriage; Means, Standard Deviations, and Differences According to $\operatorname{Sex}$

\begin{tabular}{|c|c|c|c|c|c|c|c|c|c|c|c|c|}
\hline \multirow[b]{2}{*}{ Dimensions } & \multicolumn{3}{|c|}{$\%$ Who agree } & \multicolumn{2}{|c|}{ Agreement } & \multicolumn{3}{|c|}{ Men } & \multicolumn{3}{|c|}{ Women } & \multirow{2}{*}{$\frac{\text { Diff. }}{t}$} \\
\hline & Men & Women & Total & $M$ & $S D$ & $M$ & $S D$ & $n$ & $M$ & $S D$ & $n$ & \\
\hline Sex without Marriage & 82 & 66 & 74 & 3.74 & 1.23 & 3.98 & 1.05 & 946 & 3.52 & 1.34 & 976 & $8.33^{*}$ \\
\hline Love without Marriage & 70 & 65 & 67 & 3.57 & 1.21 & 3.64 & 1.16 & 919 & 3.50 & 1.24 & 962 & $2.32^{*}$ \\
\hline Sex without Love & 63 & 33 & 47 & 2.91 & 1.44 & 3.38 & 1.34 & 940 & 2.46 & 1.40 & 976 & $14.8^{*}$ \\
\hline Love without Sex & 34 & 30 & 32 & 2.57 & 1.31 & 2.66 & 1.28 & 929 & 2.47 & 1.33 & 957 & $3.15^{*}$ \\
\hline Marriage without Sex & 18 & 21 & 19 & 2.14 & 1.18 & 2.10 & 1.14 & 933 & 2.19 & 1.22 & 952 & - \\
\hline Marriage without Love & 19 & 18 & 18 & 2,01 & 1.21 & 2.02 & 1.21 & 927 & 2.00 & 1.21 & 973 & - \\
\hline $\begin{array}{l}\text { Global myth scorc } \\
\text { (separation of the three) }\end{array}$ & - & - & - & 2.83 & 0.80 & 2.97 & 875 & 868 & 2.70 & 0.84 & 896 & $7.35^{*}$ \\
\hline
\end{tabular}

Note. Empty cells indicate statiscally nonsignificant differences.

$* p<.01$

we emphasize that the myth was expressed in its most radical form. The influence of the sociocultural factors can be seen in the significant correlations revealed between belief in this myth and age, $r=.18, p<.01$, and with the level of studies, $r=-.18, p<.01$.

7. The marriage myth. The marriage myth was accepted by $85 \%$ of the sample. These data are similar to those of other studies carried out recently abroad (Simpson et al., 1986) as well as in Spain (C.I.R.E.S., 1992). As with the majority of the other myths, women, older people, and those with a lower level of studies accepted it more, $p<.01$.

8. The couple myth. Finally, the couple myth was accepted by almost all the sample (over 95\%), whereas only $0.6 \%$ disagreed totally. Its acceptance was so overwhelming, that it ended up being independent of sex, age, or level of studies. Nevertheless, as social sciences have shown (Fisher, 1992; Ford \& Beach, 1951; Nieto, 1989; Rosenblatt \& Anderson, 1981; Wilson \& Nias, 1976), the couple is fat from inherent to human nature, nor is it present in all cultures (polygamy, etc.). Once again, we can see the immense power of what we could call "romantic socialization" on our attitudes and beliefs regarding love and romantic relationships.

We will now comment on the correlations obtained between the "general belief in myths" score with other variables studied in the investigation. Specifically, taking into consideration only the correlations higher than .20 , general belicf in myths was positively correlated with: (a) duration of the relationship, $r=.26, p=.000$ (somewhat surprisingly; maybe it can be explained by Bem's selfperception theory, 1972); (b) feelings of sexual jealousy, $r$ $=.26, p=.000$; and (c) attitude towards fidelity, $r=.25, p$ $=.000$. On the other hand, it was negatively correlated with: a) separalion of $\mathrm{scx}$, love, and matriage, $r=-.29, p=.000$; b) feeling sexual attraction towards others, $r=-.28, p=$ .000 ; and c) sexual experience, $r=-.23, p=.000$.

\section{Link between sex, love, and marriage}

Concerning the link between sex, love, and marriage (see Tables 3 and 4, and Figure 2), the results suggest that, as a rule, Spaniards tend to accept that love and sex do exist outside of marriage (although, of course, percentages are far from $100 \%$ ). However, it is difficult for the Spanish population to understand sexual relations without love, or love without sexual relations, or, even more so, marriage without sex or without love.

On the global score, obtained by averaging the scores on the six items, nearly $50 \%$ of the sample scored below 3 (that is, they disagreed with the dissociation of the dimensions), $10 \%$ scored in the explicitly medium point, another $10 \%$ was missing, and $30 \%$ scored above 3 (that is, they agreed with the dissociation of the three dimensions). Less than $5 \%$ obtained a global score of 4 or above.

Table 4

Correlations between Dissociation of Love-Sex-Marriage and Age and Studies

\begin{tabular}{lcccc}
\hline & \multicolumn{3}{c}{ Age } & \multicolumn{2}{c}{ Studies } \\
\cline { 2 - 5 } Dimensions & $r$ & $n$ & $r$ & $n$ \\
\hline Sex without Marriage & $-.40^{*}$ & 1920 & $.18^{*}$ & 1916 \\
Love without Marriage & $-.24^{*}$ & 1879 & $.15^{*}$ & 1875 \\
Sex without Love & $-.28^{*}$ & 1914 & $.16^{*}$ & 1910 \\
Love without Sex & $-.10^{*}$ & 1884 & - & 1880 \\
Marriage without Sex & - & 1883 & - & 1879 \\
Marriage without Love & - & 1898 & - & 1894 \\
\hline Global L-S-M score & $-.30^{*}$ & 1762 & $.17^{*}$ & 1758 \\
(dissociation of the three) & & & & \\
\hline
\end{tabular}

Note. Empty cells indicate statiscally nonsignificant differences. $* p<.01$ 


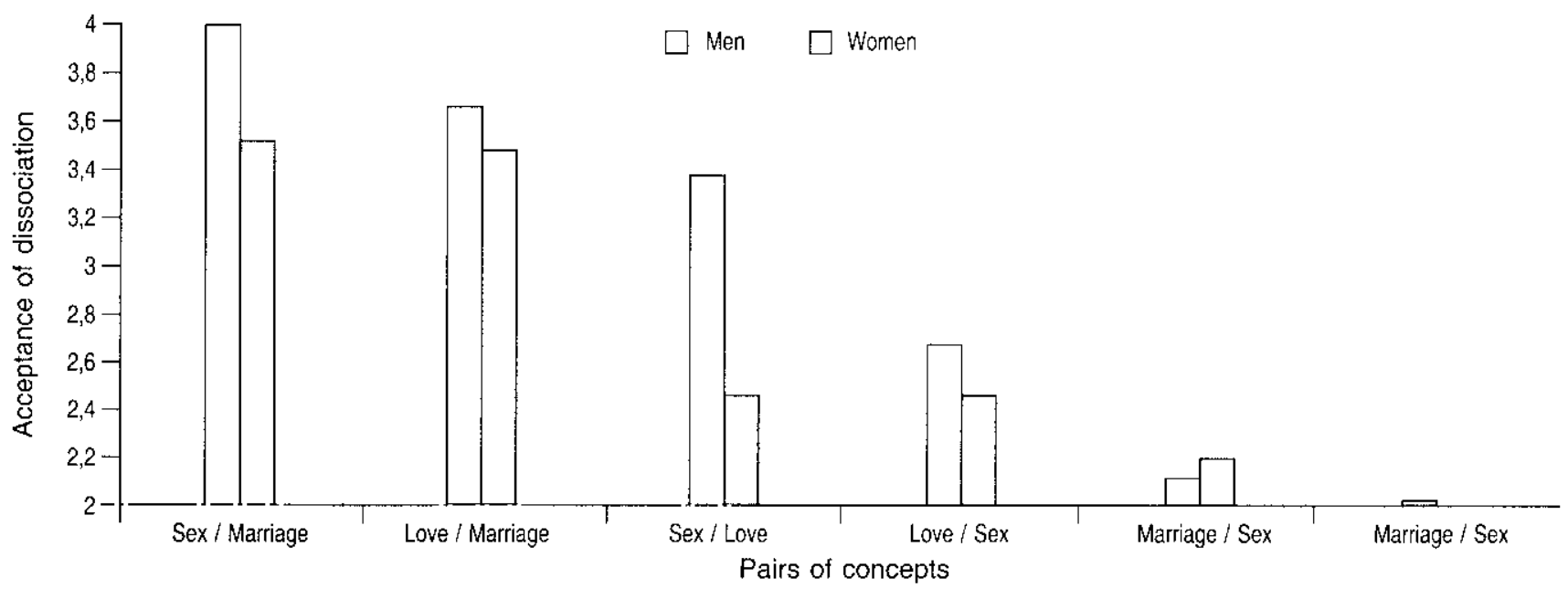

Figure 2. Acceptance of the dissociation of the pairs of concepts. (Slash means "without.") Higher columns indicatc more acceptance of the dissociation. Lower columns indicate that the dissociation of the conceps is rejected.

On the other hand, coinciding with the results obtained by other authors (Avia, Carrillo, \& Rojo, 1990; Buss \& Schmitt, 1993; Clark \& Hatfield, 1989; Foa et al., 1987; Hendrick \& Hendrick, 1992; Yela, 1995, 1998), women tended to perceive such phenomena as more closely related than men, with greater sex differences appearing in the legitimization of loveless sex or sex outside of marriage. For example, $63 \%$ of the men approved of loveless sexual relationships, as compared to $33 \%$ of the women; the difference between the means ( 3.38 vs. 2.46 for men and women, respectively) was pronounced and highly significant, $p=.000$.

As a rule, we observed a tendency for older people to perceive less dissociation between love, sex, and marriage, $r=-.30, p<.01$, especially with regard to the latter (wo. Thus, $59 \%$ of the youths (18-25 years) legitimated loveless sex, as compared to $25 \%$ of the oldest group (55-65 years). Whereas $90 \%$ of the youths approved of sex outside of marriage, this percentage dropped to $44 \%$ among the oldest group (see Table 5).

With regard to these aspects (legitimization of loveless sex, sex outside of marriage, and love without marriage), it seems that a higher level of studies coincided with permissiveness, that is to say, greater acceptance of disconnecting the three dimensions. The correlation between the "separation of sex-love-marriage" and the level of studies was $r=.17, p<.01$. Thus, among college graduates, the percentages of people that accepted such separations reached $63 \%$ (loveless sex), $85 \%$ (sex without marriage), and $74 \%$ (love without marriage), whereas among people with no studies, those percentages were $30 \%, 44 \%$, and $46 \%$, respectively. On the other hand, the concepts of loveless or sexless marriage, and love without sex were very uncommon and this did not seem to be influenced either by age or level of studies, indicating that it is a learned social factor (see Table 6).

The separation between sexual relations, love, and marriage was also moderately related with religious beliefs (agnosticsatheists' mean was 3.24 vs. the Catholics' mean. $2.74, p=$ $.000)$ and with religious behavior, $r=-.28, p=.000$.

As in the case of romantic myths, we would like to highlight the correlations of the variable "separation of sexlove-marriage" with other relevant variables of the investigation. In this case, we obtained positive correlations (always higher than .20) with: a) sexual experience, $r=.25$,

Table 5

Percentage of Acceptance of Dissociation of Love-Sex-Marriage According to Age Range

\begin{tabular}{|c|c|c|c|c|c|}
\hline \multirow[b]{2}{*}{ Dimensions } & \multicolumn{5}{|c|}{ Age ranges and number of subjects in each range } \\
\hline & $\begin{array}{c}18-24 \\
n=367\end{array}$ & $\begin{array}{c}25-34 \\
n=487\end{array}$ & $\begin{array}{c}35-44 \\
n=398\end{array}$ & $\begin{array}{c}45-54 \\
n=329\end{array}$ & $\begin{array}{c}55-64 \\
n=366\end{array}$ \\
\hline Sex without Marriage & 90 & 87 & 81 & 61 & 44 \\
\hline Love without Marriage & 77 & 78 & 71 & 60 & 47 \\
\hline Sex without Love & 59 & 58 & 52 & 37 & 25 \\
\hline Love without Sex & 34 & 36 & 35 & 28 & 24 \\
\hline Marriage without Sex & 22 & 19 & 20 & 17 & 17 \\
\hline Marriage without I_ove & 16 & 20 & 22 & 17 & 13 \\
\hline
\end{tabular}


Table 6

Percentage of Acceptance of Dissociation of Love-Sex-Marriage According to Educational Level

\begin{tabular}{|c|c|c|c|c|c|c|}
\hline \multirow[b]{2}{*}{ Dimensions } & \multicolumn{6}{|c|}{ Educational level and number of subjects in each level } \\
\hline & $\begin{array}{l}\text { None } \\
n=223\end{array}$ & $\begin{array}{l}\text { Primary } \\
n=355\end{array}$ & $\begin{array}{l}\text { Secondary } \\
n=778\end{array}$ & $\begin{array}{c}\text { Associate Degree } \\
n=208\end{array}$ & $\begin{array}{l}\text { Some College } \\
\qquad n=141\end{array}$ & $\begin{array}{c}\text { College Degrce } \\
n=145\end{array}$ \\
\hline Sex without Marriage & 44 & 57 & 82 & 91 & 80 & 85 \\
\hline Love without Marriage & 46 & 54 & 78 & 78 & 76 & 74 \\
\hline Sex without Love & 30 & 33 & 31 & 63 & 45 & 63 \\
\hline Love without Sex & 25 & 27 & 32 & 39 & 32 & 37 \\
\hline Marriage without Sex & 16 & 18 & 20 & 20 & 17 & 21 \\
\hline Marriage without Love & 15 & 15 & 19 & 18 & 20 & 27 \\
\hline
\end{tabular}

$p=.000 ;$ and b) feeling sexual attraction towards others, $r$ $=.21, p=.000$. At the same time, we obtained negative correlations with: (a) duration of the relationship, $r=-.32$, $p=.000 ;$ (b) belief in myths, $r=-.29, p=.000 ;$ and $(\mathrm{c})$ attitude towards fidelity, $r=-.20, p=.000$.

\section{Concluding Comments}

The data obtained suggest that Spanish society strongly accepts most of the romantic myths (especially older people, religious people, and people with fewer years of formal education). At the same time, women tend to be slightly more romantic than men, especially concerning the importance of sexual "loyalty" for them. Finally, with regard to beliefs about love, there secms to be an impottant trend to link love with sex and with marriage, and this is also more pronounced among women, older people, religious people, and people with fewer years of formal education.

Basically, all these general trends confirm what was expected, taking into account the roles and the implicit procedures by which people become socialized in our culture. The differences between sexes can also be explained from a sociobiological approach, though this explains more about the origin of the differences rather than their maintenance and current strength.

We believe the consequences of holding these beliefs and myths deserve some consideration. For instance, the impact that linking marriage necessarily to passionate love has on the stability of marriage. Several authors have theorized about the paradox of the stability of a social institution such as marriage, built on the existence of an emotional link as vulnerable and fluctuating as the feeling experienced in the first phases of the relationship (Liebowitz, 1983; Mathes \& Wise, 1983; Ortega y Gasset, 1917; Rougemont, 1938; Wilson \& Nias, 1976). Some of the possible negative effects that the connection betwcen passion and marriage could produce are: idealization, negative evaluation of conflict, internal attribution of negative aspects, and, above all, disappointment with the relationship.
The use of romantic myths as a standard by which to evaluate relationships generates expectations that are difficult to meet. The impossibility of maintaining the original idealization (Beck, 1988; Graziano \& Musser, 1982; Kersten \& Kersten, 1988) at times becomes a source of dissatisfaction with the relationship, which leads to typical negative behaviors (avoiding interaction, lack of emotional support towards one's partner, separate decision-making, decrease in joint activities, etc.) that make it hard to maintain the relationship (Kayser, 1993). The belief that emotion (passionate love) is a necessary and sufficient condition for maintaining a relationship leads to attitudes and behaviors that are hamful for the stability of a long-term relationship. One of these attitudes is the negative interpretation of conflict, in which contlict is considered a symptom of indifference. These internal attributions of the causes of the conflict ("if we have problems, it must mean that we don't love each other") have a negative effect on satisfaction (Bradbury \& Fincham, 1990, Barrón \& Martínez-Înigo, in press). The belief that "communicating about the situation of the relationship is destruclive, ineffectual, futile, and dangerous" (Baxter \& Wilmot, 1985), also hinders management and resolution of conflicts.

Consequently, in order to obtain satisfaction and stability in long-term relationships such as marriage, the couple should restructure and modify part of their beliefs and myths, on which they based their initial expectations before the relationship began. The study and comprehension of this restructuring process will be of great help in terms of therapeutic intervention. This is a promising trend for future research.

\section{References}

Argyle. M. (1987). The psychology of happiness. New York; Methuen.

Averill, J.R., \& Boothroyd. P. (1977). On falling in love in conformance with the romantic ideal. Motivation and Emotion, 3, 235-247. 
Avia. M.D, Carrillo, J.M., \& Rojo, N. (1990). Personalidad y diferencias sexuales: el papel del sexo, la edad y la experiencia. Revista de Psicología Social, 1, 7-22.

Barrón, A. (1990). Estrés vital, apoyo social y creencias de salud. In S. Barriga, J.M. León, M. Martínez, \& 1. Jiménez (Eds.). Psicologia de la salud (pp. 197-218). Sevilla, Spain: S.E.D.A.L.

Barrón A., \& Martinez-íñigo, D. (in press). Patrontes de auribución y estabilidad matrimonial: atribuciones de causalidad $y$ responsabilidad en una muestra de casados y divorciados. Psicothema.

Baxter, L.A., \& Wilmot, W.N. (1985). Taboo topics in close relationships, Journal of Social and Personal Relationships, 2, 253-69.

Beck, A.T. (1988). Love is never enough. New York: Guilford Press.

Bem, D.J. (1972). Self-perception theory. In L. Berkowitz (Ed.), Advances in experimental social psychology (Vol. 6). New York: Academic Press.

Bradbury, T.N., \& Fincham, F.D. (1990). Attributions in marriage: Review and critique. Prychological Bulletin, 107, 3-33.

Burgess, E.W., \& Locke. H.J. (1945). The family: From institution to companionships. New York: American Book.

Buss, D.M., \& Schmitt. D.P. (1993). Sexual strategies theory: An evolutionary perspective on human mating. Psychological Review, 100, 204-32.

Buunk, B., \& Bringle, R.G. (1987). Jealousy in love relationships. In D. Perlman, \& S.W. Duck (Eds.), Intimate relationships (pp.123-148). Beverly Hills, CA: Sage.

Cancian, F. (1987), Love in America: Gender and self-development. Cambridge, MA: Cambridge University Press.

C.I.R.E.S. (Centro de Investigaciones de la Realidad Social) (1992). La realidad social en España. Erandio, Spain: Ellacuría.

Clark, R.D., \& Hatfield, E. (1989). Gender differences in receptivity to sexual offers. Joumal of Psychology and Human Sexuality. 2, 39-55.

Cook, M., \& McHenry, R. (1978), Sexual atraction. Oxford, UK: Pergamon Press.

Crosby. J.F. (1973). Illusion and disillusion: The self in love and marriage. Belmont, CA: Wadsworth.

Dion, K.K., \& Dion K.L. (1996). Cultural perspective on romantic love. Personal Relarionships, 3, 5-17.

Dion, K.L., \& Dion. K.K. (1979). Personality and behavior correlates of romantic love. in M. Cook \& G. Wilson (Eds.). Love and atraction (pp, 213-220). Oxford, UK: Pergamon Press.

Ellis, A.. \& Grieger, R. (1977). Handbook of rational-emotive therapy. New York: Springer-Veriag.

Fisher. H. (1992). The anatomy of love. New York; Norton.

Foa, V.G., Anderson. B., Converse Jr. J., Urbansky, W.A., Cawley, M.J., Muhlhausen, S.M.. \& Tornblom, K.Y. (1987). Genderrelated sexual attitudes: Some cross-cultural similarities and differences. Sex Roles. 16.511-519.

Ford, C.S., \& Beach, F.A. (1951). Paterns of sexial behavior. New York: Harper \& Row.

Frijda, N. H. (1988). The liws of emotion. American Psychologist. $5,349-358$.
Good. L.R. (1976). Belief in romantic love. Psychology, 13, 6-7.

Goode. W.J. (1959). The theoretical importance of tove. American Sociological Revew, 24. 38-47.

Graziano. W. \& Musser. L.M. (1982). The joining and the parting of the ways. In S.W. Duck (Ed.), Personal relationships 4: Dissolving personal relationships (pp. 75-106). London: Acaderuic Press.

Hendrick, S., \& Hendrick, C. (1992). Liking, loving, and relating. Pacific Grove, CA: Brooks Cole.

Hetch, M., Marston, P.J., \& Larkey, L.K. (1994). Love ways and relationships quality. Joumal of Social and Personal Relationships, H, 25-43.

Houston. L.N. (1981). Romanticism and croticism among Bjack and White coljege students. Adolescence, 16, 263-72.

Iglesias de Ussel, J. (1987). Sociologia del noviazo en España. Granada, Spain: Caja General de Ahorros y Monte de Piedad de Granada.

Jankowiak, W.R., \& Fischer, E.F. (1992). A cross-cultural perspective on romantic love. Ethnology, 3/, 149-155.

Kayser. K. (1993). When love dies: The process of marital disaffection. New York: Guilford Press.

Kersten, K.K.. \& Kersten. L.K. (1988). Marriage and the family: Studving close relationship.s. Now York: Harper \& Row.

l.iebowilz. M.R. (1983). The chemistry of love. Boston. MA: Little Brown.

Malo de Molina, C. (1992). Los españoles y la sexualidad. Madrid: Temas de Hoy.

Martín Gaite, C. (1987). Usos amomsos en la España del s. XVIII. Barcelona: Anagrama.

Martínez-Ĩñigo, D. (1997). Aspectos psicosociales de los procesos de disolución de las relaciones interpersonales intimas. Unpublished doctoral dissertation. Complutense University of Madrid, Spain.

Mathes, E.W., \& Wise. P.S. (1983). Romantic love and the ravages of time. Psychological Reports, 53, 839-846.

Nieto, J.A. (1989). Cultura y sociedad en las prácticas sexuales. Madrid: Fundación Universidad-Empresa.

Noller. P. (1996). What is this thing called love? Defining the love that supports martiage and family. Persomal Relationships, 3 , 97-115.

Ortega y Gassec. J. (1917). Parib la cultura del anor. Obras Completas (1" ed., Vol. II. pp. 138-145). Madrid: Revista de Occidence.

Ortega y Gasset, J. (1926). Sobrc el "amor cortés." Obras Comple'as (1" ed. Vol. III. pp. 442-446). Madrid: Revista de Occidente.

Orlega y Gasset, J. (1952). Prologo a "El Collar de la Paloma." Obras Completas (1 ${ }^{\text {sl }}$ ed. Vol. VII, pp. 41-55). Madrid: Alianza/Revista de Occidente.

Peele, S. (1975). Love and addiction. New York: Taplinger.

Rosenblatt, P.C., \& Anderson, R.M. (1981). Human sexuality in cross-cultural perspective. In M. Cook (Ed), The bates of humam sexual atraction (pp. 215-250). New York: Academic Press.

Rougemont. D. (1938). Lamour et LOccident. Paris: Librarie Plun. 
Schael, A.W. (1989). Exape from intimacy: The preudo-relationship addictions. San Francisco, CA: Harper \& Row.

Simun, R.W., Eder, D., \& Evans, C. (1992). The development of feeling norms underlying romantic love among adolescent females. Social Psychology Quarterty, 55, 29-46.

Simpson, JA., Camphell. B., \& Berscheid, E. (1986). The association between romantic love and marriage: Kephart twice revisited. Personality and Social Psychology Bulletin, 12. 363-72.

Skinner, B.F. (1953). Science and humon behavior. New York: Macmillan.

Solomon, R.C. (1988). About love. New York: Simon \& Schuster.

Solomon, R.L. (1980). The opponent process theory of acquired motivation: The costs of pleasure and the benefits of pain. American Psychologist, 35, 691-712.

Sternberg, R.J. (1988). The triangle of love: Intimacy, passion, commitment. New York: Basic Books.

Tennov, D. (1979). Love and limerance. New York: Stein Day.

Van Sommers, P. (1987). Jealousy What is it? Who feels it? London: Penguin.
Wilson, G. (1981). The Coolidge effect:An evolutionary account of human sexuality. New York: Morrow.

Wilson, G., \& Nias, D. (1976). Love's mysteries. Glasgow, UK: Collins

Yela, C. (1995). Análisis psico-sociológico del comportamiento amoroso. Unpublished doctoral dissertation. Complutense University of Madrid, Spain.

Yela, C. (1996). Componentes básjcos del amor: algunas matizaciones al modelo de Sternberg. Revista de Psicologia Social, 11, 185201 .

Yeta, C. (1997). Curso temporal de los componentes básicos del amor a lo largo de la relación de pareja. Psicothenta, 9, 1-15.

Yela, C. (1998). Diferencias entre sexos en los juicios verbales sobre su comportamiento amoroso y sexual. Revista de Psicologia General y Aplicada, 51. 115-147.

Received May 5, 1997

Revision received March 31, 1998

Accepted March 3, 1999 